Hal 7-16

\title{
FAKTOR-FAKTOR YANG BERHUBUNGAN DENGAN PEMBERIAN KOLOSTRUM PADA BAYI BARU LAHIR OLEH IBU POST OP SECTIO CAESAREA DI RS PMC KOTA PEKANBARU \\ Elfiza Fitriami ${ }^{1}$, Reny Afwinasyah ${ }^{2}$
}

\author{
Sekolah Tinggi Ilmu Kesehatan Pekanbaru Medical Center ${ }^{1}$ \\ RSUD Arifin Achmad Provinsi Riau ${ }^{2}$ \\ Email: elfizafitriamy26@gmail.com
}

\begin{abstract}
ABSTRAK
Latar Belakang: Pemberian kolostrum secara awal pada bayi baru lahir merupakan perlindungan yang terbaik. Beberapa hal yang dapat memengaruhi keberhasilan pemberian kolostrum dijam pertama kelahiran misalnya untuk ibu Sectio Caesarea. Sebagian ibu Sectio Caesarea tidak setuju untuk memberikannya pada hari pertama, meskipun ibu mengetahui tentang pentingnya pemberian ASI. Faktor yang memengaruhi ibu dalam memberikan kolostrum pada bayi yang paling utama adalah tingkat pengetahuan. Selain itu tingkat pendidikan ibu mempunyai pengaruh dalam pemberian kolostrum. Dukungan keluarga juga merupakan faktor eksternal yang paling besar pengaruhnya terhadap keberhasilan pemberian kolostrum. Tujuan: untuk mengetahui faktor - faktor yang berhubungan dengan pemberian kolostrum pada bayi baru lahir oleh ibu post op sectio caesarea. Metode: jenis penelitian ini bersifat kuantitatif, menggunakan cross sectional, sampel dalam penelitian ini 30 ibu post op caesarea. Hasil Penelitian: ada hubungan tingkat pendidikan ibu dengan pemberian kolostrum pada ibu post op caesarea ( $p: 0,010)$, ada hubungan tingkat pengetahuan ibu dengan pemberian kolostrum pada ibu post op caesarea $(p=0,006)$, ada hubungan dukungan keluarga dengan pemberian kolostrum pada ibu post op caesarea $(p: 0,02)$. Kesimpulan : ada hubungan signifikan tingkat pendidikan, tingkat pengetahuan dan dukungan keluarga terhadap pemberian kolostrum pada bayi baru lahir oleh ibu post op sectio caesarea.
\end{abstract}

Kata Kunci : Bayi Baru Lahir, Dukungan Keluarga, Kolostrum, Post Op Sectio Caesarea, Tingkat Pendidikan, Tingkat Pengetahuan.

\begin{abstract}
Background: Early administration of colostrum to newborns is the best protection. Several things can affect the success of giving colostrum in the first hour of birth, for example for women with Caesarean section. Some women with Caesarean section do not agree to give it on the first day, even though they know about the importance of breastfeeding. The most important factor affecting mothers in giving colostrum to babies is the level of knowledge. In addition, the mother's education level has an influence in giving colostrum. Family support is also an external factor that has the greatest influence on the success of giving colostrum. Purpose: to determine the factors that are associated with the provision of colostrum to newborns by post-op sectio caesarean mothers. Methods: This type of research is quantitative, using cross-sectional, the sample in this study is 30 post-op caesarean mothers. Results: data obtained that there is a relationship between the level of maternal education and the provision of colostrum to post-op caesarean mothers ( $\mathrm{p}: 0.010$ ), there is a relationship between the level of maternal knowledge and the provision of colostrum to post-op caesarean mothers $(p=0.006)$, there is a
\end{abstract}


relationship between family support and provision colostrum in post-op caesarean mothers (p: 0.02). Conclusion: there is a significant relationship between education level, knowledge level and family support for colostrum administration in newborns by post-op sectio caesarean mothers.

Keywords: Newborns, Family Support, Colostrum, Post Op Sectio Caesarea, Education Level, Knowledge Level.

\section{Latar Belakang}

Kolostrum merupakan air susu yang pertama kali keluar seringkali berwarna kuning atau dapat pula jernih yang mengandung sel hidup yang menyerupai "sel darah putih" yang dapat membunuh kuman penyakit sehingga mampu melindungi tubuh bayi dari berbagai penyakit infeksi. Pemberian kolostrum secara awal pada bayi baru lahir secara terusmenerus merupakan perlindungan yang terbaik. Kandungan yang ada pada kolostrum banyak protein dan antibody, walaupun sangat kental dan jumlahnya sangat sedikit (Maryunani, 2012).

Pada masa awal menyusui, kolostrum yang keluar mungkin hanya sesendok teh. Meskipun sedikit, kolostrum mampu melapisi usus bayi dan melindunginya dari bakteri serta sanggup mencukupi kebutuhan nutrisi bayi pada hari pertama kelahirannya. Selanjutnya, secara berangsur-angsur produksi kolostrum berkurang saat air susu keluar pada hari ketiga sampai kelima (Halimatusyadiah, 2019).

Berdasarkan data profil kesehatan Indonesia ASI mengandung kolostrum yang kaya akan antibodi karena mengandung protein untuk daya tahan tubuh dan pembunuh kuman dalam jumlah tinggi sehingga pemberian ASI eksklusif dapat mengurangi risiko kematian pada bayi (Kementerian Kesehatan RI, 2020).

Untuk menurunkan angka kematian pada bayi United Nation Children Fund ( UNICEF) dan World Health Organization merekomendasikan pemberian kolostrum segera setelah bayir lahir dan memberikan ASI eksklusif sampai bayi berusia 6 bulan, sebagaimana diatur dalam Peraturan Pemerintah Republik Indonesia No 33 Tahun 2012 tentang pemberian ASI eksklusif menyatakan setiap bayi berhak mendapatkan ASI eksklusif sejak dilahirkan selama 6 bulan, kecuali atas indikasi medis (Permen RI, 2012).

Prevalensi pemberian kolostrum di Indonesia masih rendah.Hal ini ditunjukkan dalam pelaksanaan Inisiasi Menyusu Dini (IMD) yang masih lebih rendah dari angka cakupan praktik inisiasi menyusu dini di dunia yaitu sebesar $42 \%$, sedangkan di Indonesia hanya 39\%. Angka ini masih sangat rendah jika dibandingkan dengan negara lain di sebagian negara Asia Tenggara misalnya Myanmar (76\%), Thailand (50\%), dan Filipina (54\%).

Ada banyak hal yang dapat memengaruhi keberhasilan pemberian kolostrum pada ibu setelah melahirkan, namun pemberian ASI dijam pertama kelahiran tidak dapat dilakukan oleh ibu yang memiliki masalah 
pada persalinannya, misalnya untuk ibu Sectio Caesarea (Harun, 2017). Air susu ibu (ASI) ada yang sudah keluar pertama namun sebagian ibu Sectio Caesarea tidak setuju untuk memberikannya pada hari pertama, meskipun ibu mengetahui tentang pentingnya pemberian ASI. Alasan ibu tidak melakukan inisiasi hari pertama yaitu bayi yang belum dirawat gabung, ibu belum bisa duduk atau mobilisasi dan ASI yang belum keluar (Anasari, 2014).

Kondisi kelemahan akibat pengaruh anestesi yang diberikan sebelumnya. Kegagalan pemeberian inisiasi menyusui dini tersebut juga akan berpengaruh pada produksi ASI ibu, karena hormon aksitosin yang berpengaruh pada produksi ASI ibu akan dilepaskan jika dipacu dengan isapan bayi pada puting ibu saat menyusui. Sementara itu, bayi tetap membutuhkan ASI sebagai nutrisi dan juga meningkatkan imunitas tubuhnya. Jika tidak terjadi keseimbangan antara produksi ASI ibu dengan kebutuhan ASI yang diperlukan oleh bayi, maka akan berakibat kegagalan program ASI eksklusif 6 bulan pada bayi (Soetjiningsih, 2018).

Faktor yang memengaruhi ibu dalam memberikan kolostrum pada bayi yang paling utama adalah tingkat pengetahuan. Tingkat pendidikan ibu mempunyai pengaruh dalam pemberian kolostrum. Makin tinggi tingkat pendidikan ibu makin rendah prevalensi menyusui segera setelah lahir. Penelitian Suwardi (2019). Dukungan keluarga merupakan faktor eksternal yang paling besar pengaruhnya terhadap keberhasilan ASI eksklusif. Adanya dukungan keluarga terutama suami maka akan berdampak pada peningkatan rasa percaya diri atau motivasi dari ibu dalam menyusui (Sitopu, 2017).

Berdasarkan survei awal yang dilakukan di ruang kebidanan RS Pekanbaru Medical Center pada bulan Mei 2021, didapatkan hasil bahwa di ruangan melati RS PMC Dokter anak dan perawat sudah menganjurkan pemberian kolostrum pada bayi, dari 10 responden yang melakukan persalinan, 8 ibu dengan persalinan Sectio Caesarea, 7 ibu sudah memberikan kolostrum kepada bayi 2 responden tidak mengetahui tentang kolostrum sehingga tidak memberikan kolostrum kepada bayi, dengan tingkat pendidikan $5 \mathrm{ibu}$ pendidikan terakhir SMA. Kolostrum yang keluar pada hari kedua setelah kelahiran dibuang oleh ibu. ibu mengatakan kolostrumnya tidak keluar sehingga bayi menangis terus karena masih haus dan dari keluarga juga tidak mengerti tentang kolostrum sehingga tidak memberikan dukungan kepada ibu untuk memberikan kolostrum kepada bayinya.

Berdasarkan paparan di atas, penulis tertarik membahas tentang faktor -faktor yang berhubungan dengan pemberian kolostrum pada bayi baru lahir oleh ibu post op sectio caesarea.

\section{Metode Penelitian}

Penelitian ini merupakan penelitian kuantitatif. Metode yang digunakan adalah cross sectional yaitu suatu penelitian untuk mempelajari dinamika korelasi antara faktor- 
faktor risiko dengan efek, artinya tiap subjek penelitian hanya diobservasi sekali saja dan pengukuran dilakukan terhadap status kerakter atau variabel subjek pada saat pemeriksaan, tujuan penelitian ini untuk mengamati hubungan antara faktor risiko dengan akibat yang terjadi berupa penyakit atau keadaan kesehatan tertentu dalam waktu yang bersamaan, ditanya masalahnya (akibat) sekaligus penyebabnya (faktor risiko).

Populasi yang digunakan dalam penelitian ini adalah ibu post op caesarea di Rumah Sakit Pekanbaru Medical Center dengan jumlah rata - rata ibu perbulan sebanyak $66 \mathrm{ibu}$ selama 3 bulan terakhir. Jumlah sampel pada penelitian ini adalah 30 orang. Teknik pengambilan sampel menggunakan Accidental sampling.

Instrument penelitian yang digunakan adalah kuesioner tentang tingkat pendidikan, tingkat pengetahuan, dukungan keluarga dan pemberian kolostrum pada bayi baru lahir.

Analisis univariat dilakukan untuk mendeskripsikan pendidikan, pengetahuan, dukungan keluarga dan pemberian kolostrum menggunakan distribusi frekuensi. Analisis bivariat dilakukan untuk mengetahui hubungan pendidikan, pengetahuan, dan dukungan keluarga dengan pemberian kolostrum menggunakan uji chi square.

\section{Hasil Penelitian}

\section{Analisis Univariat}

\section{Tingkat Pendidikan}

Dari hasil penelitian terkait karakteristik respoden berdasarkan tingkat Pendidikan ditampilkan pada tabel 1.

Tabel 1

Distribusi Frekuensi Berdasarkan Pendidikan Terakhir Responden di RS.PMC Kota Pekanbaru tahun $2021(\mathrm{~N}=30)$

\begin{tabular}{ccc}
\hline Pendidikan & Frekuensi & Persentase(\%) \\
\hline SMP & 4 & 13.3 \\
SMA & 24 & 80.0 \\
Sarjana/PT & 2 & 6.7 \\
\hline Total & 30 & 100,0 \\
\hline
\end{tabular}

Tabel 1 menunjukkan bahwa dari 30 responden yang diteliti berdasarkan tingkat pendidikan terakhir Mayoritas berpendidikan SMA yaitu sebanyak 24 orang responden $(80,0 \%)$.

\section{Tingkat Pengetahuan}

Dari hasil penelitian terkait karakteristik respoden berdasarkan tingkat pengetahuan ditampilkan pada tabel 2.

Tabel 2

Distribusi Frekuensi Responden

Berdasarkan Tingkat Pengetahuan Responden di RS.PMC Kota Pekanbaru tahun $2021(\mathrm{~N}=30)$

\begin{tabular}{ccc}
\hline $\begin{array}{c}\text { Tingkat } \\
\text { Pengetahuan }\end{array}$ & Frekuensi & Persentase(\%) \\
\hline Baik & 8 & 26.7 \\
Cukup & 14 & 46.7 \\
Kurang & 8 & 26.7 \\
\hline Total & 30 & 100,0 \\
\hline
\end{tabular}

Tabel 2 menunjukkan bahwa dari 30 responden yang diteliti, Mayoritas memiliki 
pengetahuan yang cukup yaitu sebanyak 14 responden $(46,7 \%)$.

\section{Dukungan Keluarga}

Dari hasil penelitian terkait dukungan keluarga ditampilkan pada tabel 3.

Tabel 3

Distribusi Frekuensi Berdasarkan Dukungan

Responden di RS.PMC Kota Pekanbaru tahun $2021(\mathrm{~N}=30)$

\begin{tabular}{ccc}
\hline $\begin{array}{c}\text { Dukungan } \\
\text { Keluarga }\end{array}$ & Frekuensi & Persentase(\%) \\
\hline Baik & 20 & 66.7 \\
Kurang Baik & 10 & 33.3 \\
\hline Total & 30 & 100,0 \\
\hline
\end{tabular}

Tabel 3 menunjukkan bahwa dari 30 responden yang diteliti sebagian besar Sebagian besar responden mendapatkan Dukungan Keluarga yang kurang baik yaitu sebanyak 20 orang responden $(66,7 \%)$.

\section{Pemberian Kolostrum}

Dari hasil penelitian tentang pemberian kolostrum ASI ditampilkan pada table 4.

Tabel 4

Distribusi Frekuensi Berdasarkan Pemberian Kolostrum Oleh Responden di RS.PMC Kota Pekanbaru tahun $2021(\mathrm{~N}=30)$

\begin{tabular}{ccc}
\hline $\begin{array}{c}\text { Pemberian } \\
\text { Kolostrum }\end{array}$ & Frekuensi & Persentase(\%) \\
\hline $\begin{array}{c}\text { Memberikan } \\
\text { Tidak }\end{array}$ & 24 & 80.0 \\
memberikan & 6 & 20.0 \\
\hline Total & 30 & 100,0 \\
\hline
\end{tabular}

Tabel 4 menunjukkan bahwa dari 30 responden yang diteliti berdasarkan pemberian kolostrum mayoritas memberikan kolostrum yaitu sebanyak 24 responden $(80.0 \%)$.

\section{Analisis Bivariat}

1. Hubungan Tingkat Pendidikan Ibu dengan Pemberian Kolostrum pada Bayi Baru Lahir Oleh Ibu Post Op Caesarea

Dari hasil penelitian menunjukan adanya hubungan antara tingkat Pendidikan ibu dengan pemberian kolostrum pada bayi baru lahir ditampilkan pada table 5 .

Tabel 5

Hubungan Tingkat Pengetahuan Ibu Post Op Sectio Caesarea Dengan Pemberian Kolostrum Pada Bayi Baru Lahir Di RS.PMC Kota Pekanbaru Tahun 2021 $(\mathrm{N}=30)$

\begin{tabular}{|c|c|c|c|c|c|c|c|c|c|}
\hline \multirow{3}{*}{ Kolostrum } & \multicolumn{6}{|c|}{ Tingkat Pendidikan } & \multicolumn{2}{|c|}{ Total } & \multirow{3}{*}{$\begin{array}{c}\text { Nilai } \\
p \\
\text { value }\end{array}$} \\
\hline & \multicolumn{2}{|c|}{ SMP } & \multicolumn{2}{|c|}{ SMA } & \multicolumn{2}{|c|}{ PT } & & & \\
\hline & $\mathbf{N}$ & $\%$ & $\mathbf{N}$ & $\%$ & $\mathbf{N}$ & $\%$ & $\mathbf{N}$ & $\%$ & \\
\hline Memberikan & 0 & 0,0 & 22 & 73.3 & 2 & $\begin{array}{c}6,6 \\
7\end{array}$ & 24 & 100 & \\
\hline $\begin{array}{c}\text { Tidak } \\
\text { Memberikan }\end{array}$ & 4 & 13,3 & 2 & 6,67 & 0 & 0.0 & 6 & 100 & \\
\hline TOTAL & 4 & 13.3 & 24 & 80.0 & 2 & 6.7 & 30 & 100 & \\
\hline
\end{tabular}

Tabel 5 Hasil analisis hubungan Pendidikan Ibu Post Op Sectio Caesarea Dengan Pemberian Kolostrum Pada Bayi Baru Lahir didapatkan bahwa dari 30, responden yang memberikan Kolostrum dengan pendidikan terakhir SMP tidak ada. SMA sebanyak 22 ibu (73.3\%). sedangkan ibu yang merupakan tamatan perguruan tinggi sebanyak 2 ibu (8,3\%). Hasil menunjukkan hubungan Pendidikan Ibu Post Op Sectio Caesarea Dengan Pemberian Kolostrum Pada Bayi Baru Lahir.

Ibu yang tidak memberikan Kolostrum dengan Pendidikan terakhir SMP sebanyak 4 ibu (13,3\%), ibu yang memiliki 
Pendidikan terakhir SMA sebanyak 2 ibu $(6,67 \%)$.

Hasil analisis bivariate chi square nilai $p$ value $=0,010<(0,05)$ maka Ha diterima Ada hubungan Pendidikan ibu Post $O p$ Sectio Caesarea dengan pemberian kolostrum pada bayi baru lahir di RS.PMC Kota Pekanbaru tahun 2021.

\section{Hubungan Tingkat Pengetahuan Ibu} dengan Pemberian Kolostrum pada Bayi Baru Lahir Oleh Ibu Post Op Caesarea

Dari hasil penelitian menunjukan adanya hubungan antara tingkat Pendidikan ibu dengan pemberian kolostrum pada bayi baru lahir yang ditampilkan pada tabel 6 .

Tabel 6

Hubungan Tingkat Pengetahuan Ibu Post Op Sectio Caesarea Dengan Pemberian Kolostrum Pada Bayi Baru Lahir Di RS.PMC Kota Pekanbaru Tahun $2021(\mathrm{~N}=30)$

\begin{tabular}{|c|c|c|c|c|c|c|c|c|c|}
\hline \multirow{3}{*}{ Kolostrum } & \multicolumn{6}{|c|}{ Tingkat Pengetahuan } & \multicolumn{2}{|c|}{ Total } & \multirow{3}{*}{$\begin{array}{l}\text { Nilai } \\
p \text { value }\end{array}$} \\
\hline & \multicolumn{2}{|c|}{ Baik } & \multicolumn{2}{|c|}{ Cukup } & \multicolumn{2}{|c|}{ Kurang } & & & \\
\hline & $\mathbf{N}$ & $\%$ & $\mathbf{N}$ & $\%$ & $\mathbf{N}$ & $\%$ & $\mathbf{N}$ & $\%$ & \\
\hline Memberikan & 8 & 26,67 & 14 & 46.7 & 2 & 6,67 & 24 & 100 & \\
\hline $\begin{array}{c}\text { Tidak } \\
\text { Memberikan }\end{array}$ & 0 & 0.0 & 0.0 & 0.0 & 6 & 20 & 6 & 100 & \\
\hline TOTAL & 8 & 26,67 & 14 & 46.7 & 8 & 26,67 & 30 & 100 & \\
\hline
\end{tabular}

Tabel 6 Hasil analisis hubungan tingkat Pengetahuan Ibu Post Op Sectio Caesarea Dengan Pemberian Kolostrum Pada Bayi Baru Lahir didapatkan bahwa dari 30 responden yang memberikan Kolostrum dengan pengetahuan yang baik 8 ibu $(26,67 \%)$ yang memiliki pengetahuan cukup sebanyak 14 ibu $(46,6 \%)$ sedangkan yang kurang sebanyak 2 ibu (6,67\%). Hasil menunjukkan hubungan tingkat
Pengetahuan Ibu Post Op Sectio Caesarea Dengan Pemberian Kolostrum Pada Bayi Baru Lahir.

Ibu yang tidak memberikan Kolostrum dengan pengetahuan yang baik dan ccukup tidak ada, dan yang memiliki pengetahuan kurang sebanyak 6 ibu (20\%). Dengan demikian dapat disimpulkan bahwa mayoritas ibu yang memberikan kolostrum adalah ibu dengan pengetahuan yang Cukup.

Didapatkan hasil analisis bivariate chi square nilai $p$ value $=0,006<(0,05)$ maka Ha diterima Ada hubungan Pengetahuan ibu Post Op Sectio Caesarea dengan pemberian kolostrum pada bayi baru lahir di RS.PMC Kota Pekanbaru tahun 2021.

3. Hubungan Dukungan Keluarga dengan Pemberian Kolostrum pada Bayi Baru Lahir Oleh Ibu Post Op Caesarea

Dari hasil penelitian menunjukan adanya hubungan dukungan keluarga ibu post op sectio caesarea dengan pemberian kolostrum pada bayi baru lahir ditampilkan pada tabel 7.

Tabel 7

Hubungan Dukungan Keluarga Ibu Post Op Sectio Caesarea Dengan Pemberian Kolostrum Pada Bayi Baru Lahir Di RS.PMC Kota Pekanbaru Tahun 2021. $(\mathrm{N}=30)$

\begin{tabular}{|c|c|c|c|c|c|c|c|}
\hline \multirow{3}{*}{ Kolostrum } & \multicolumn{4}{|c|}{ Dukungan Keluarga } & \multirow{2}{*}{\multicolumn{2}{|c|}{ Total }} & \multirow{3}{*}{$\begin{array}{c}\text { Nilai } \\
p \text { value }\end{array}$} \\
\hline & \multicolumn{2}{|c|}{ Baik } & \multicolumn{2}{|c|}{$\begin{array}{c}\text { Kurang } \\
\text { baik }\end{array}$} & & & \\
\hline & $\mathbf{N}$ & $\%$ & $\mathbf{N}$ & $\%$ & $\mathbf{N}$ & $\%$ & \\
\hline Memberikan & 20 & 66,7 & 4 & 13,3 & 24 & 100 & \\
\hline $\begin{array}{c}\text { Tidak } \\
\text { memberikan }\end{array}$ & 0 & 0.0 & 6 & 20 & 6 & 100 & \\
\hline TOTAL & 20 & 66.7 & 10 & 33.3 & 30 & 100 & \\
\hline
\end{tabular}


Tabel 7 Hasil analisis hubungan Dukungan Keluarga Ibu Post Op Sectio Caesarea Dengan Pemberian Kolostrum Pada Bayi Baru Lahir didapatkan bahwa dari 30 responden $(100,0 \%)$ yang memberikan Kolostrum dengan Dukungan Keluarga yang baik sebanyak 20 ibu $(66,7 \%)$, Sedangkan ibu dengan Dukungan Keluarga kurang baik sebanyak 4 ibu $(13,3 \%)$. Hasil menunjukkan hubungan Dukungan Keluarga Ibu Post Op Sectio Caesarea Dengan Pemberian Kolostrum Pada Bayi Baru Lahir.

Ibu yang tidak memberikan Kolostrum dengan Dukungan Keluarga kurang baik sebanyak 6 ibu (20\%). Dengan demikian dapat disimpulkan bahwa Mayoritas ibu dengan dukungan keluarga yang baik memberikan kolostrum kepada bayinya.

Hasil analisis bivariate Fisher's Exact Test nilai $p$ value $=0,02<(0,05)$ maka Ha diterima Ada hubungan Dukungan keluarga Pendidikan ibu Post Op Sectio Caesarea dengan pemberian kolostrum pada bayi baru lahir di RS.PMC Kota Pekanbaru tahun 2021.

\section{Pembahasan}

\section{Tingkat Pendidikan}

Berdasarkan gambaran karakteristik responden di dapatkan bahwa dari 30 responden yang diteliti berdasarkan tingkat pendidikan terakhir Mayoritas berpendidikan SMA yaitu sebanyak 24 orang responden (80\%).

$$
\text { Menurut Siagian }
$$
menyatakan semakin tinggi tingkat pendidikan seseorang, maka akan semakin tinggi keinginannya untuk menggunakan pengetahuan dan keterampilan yang dimilikinya. Penggunaan pengetahuan akan meningkatkan pemahaman seseorang terhadap sesuatu objek yang tentu saja akan mempengaruhi persepsinya terhadap objek tertentu.

Menurut analisapeneliti semakin tinggi pendidikan seseorang akan semakin banyak seseorang tersebut tahu, dan akan semakin bijak dalam mengambil keputusan untuk memberikan yang terbaik bagi anak ataupun keluarganya.

\section{Tingkat Pengetahuan}

Berdasarkan gambaran karakteristik responden di dapatkan bahwa dari 30 responden yang diteliti mayoritas tingkat pengetahuan ibu cukup sebanyak 14 ibu $(46,7 \%)$.

Ibu yang mempunyai pengetahuan yang baik tentang pemberian kolostrum dan memahami arti pentingnya kolostrum bagi perkembangan bayi, secara otomatis apabila anak maupun ibu tidak sakit dapat memberikan kolostrum sedini mungkin pada bayinya. Begitu juga sebaliknya, ibu yang mempunyai pengetahuan yang kurang baik maka akan menunda pemberian kolostrum kepada bayinya (Astari \& Nurazizah, 2019). 
Menurut analisa peneliti ibu yang memiliki pengetahuan baik akan mengerti dan memahami manfaat dari pemberian kolostrum, dan akan berusaha memberikan kolostrum untuk bayinya.

\section{Dukungan Keluarga}

Berdasarkan gambaran karakteristik responden di dapatkan bahwa dari 30 responden yang diteliti mayoritas dukungan keluarga kurang baik sebanyak 20 responden $(66,7 \%)$

Menurut Sitopu (2017), dukungan keluarga mempunyai hubungan dengan suksesnya pemberian kolostrum kepada bayi. Dukungan keluarga adalah dukungan untuk memotivasi ibu dalam memberikan kolostrum kepada bayinya, serta memberikan dukungan psikologis kepada ibu setelah melahirkan.

Menurut analisa peneliti jika dukungan keluarga baik, maka ibu akan mempunyai semangat dan dukungan dalam pemberian kolostrum kepada bayinya.

\section{Hubungan tingkat pendidikan dengan} pemberian kolostrum pada bayi baru lahir oleh ibu post op caesarea

Pada Faktor Pendidikan Hasil analisis bivariate chi square nilai $p$ value = $0,010<(0,05)$ maka Ha diterima Ada hubungan Pendidikan ibu Post Op Sectio Caesarea dengan pemberian kolostrum pada bayi baru lahir di RS.PMC Kota Pekanbaru tahun 2021.

Sejalan dengan pernyataan Elinofia, bahwa dimana pendidikan merupakan pedoman dalam membentuk tindakan seseorang.Perilaku baru khususnya pada orang dewasa diawali oleh pengetahuan, selanjutnya muncul sikap terhadap objek yang diketahuinya. Setelah objek diketahui dan disadari sepenuhnya kemudian timbul respon berupa tindakan (Elinofia et al., 2019).

\section{Hubungan tingkat pengetahuan dengan} pemberian kolostrum pada bayi baru lahir oleh ibu post op caesarea

Hasil analisis bivariate chi square nilai $p$ value $=0,006<(0,05)$, ada hubungan yang signifikan antara Pengetahuan dengan Pemberian kolostrum oleh Ibu Post Op Sectio Caesarea Pada Bayi Baru Lahir di RS PMC tahun 2021.

Sejalan dengan hasil penelitian Anasari (2014) yang mengungkapkan bahwa perilaku yang didasari oleh pengetahuan akan lebih harmonis dari pada perilaku yang tidak didasari pengetahuan. Pengetahuan merupakan faktor yang sangat penting untuk terbentuknya tindakan seseorang. Hal ini didukung pula dengan penelitian yang dilakukan oleh Septiani \& Ummami (2020) menunjukan bahwa ada hubungan yang cukup kuat antara pengetahuan ibu tentang ASI dengan pemberian kolostrum ( $p$ value $=0,001$ ).

Menurut analisa peneliti Tingkat pengetahuan gizi yang rendah merupakan salah satu faktor yang menghambat perbaikan gizi. Kolostrum yang terdapat dalam ASI jumlahnya tidak banyak tetapi 
kaya akan zat-zat gizi dan sangat baik untuk dikonsumsi bayi. Tetapi karena faktor kekurangtahuan atau kepercayaan yang salah, banyak ibu yang baru melahirkan tidak memberikan kolostrum pada bayinya.

\section{Hubungan dukungan keluarga dengan} pemberian kolostrum pada bayi baru lahir oleh ibu post op caesarea

Hasil analisis bivariate Fisher's Exact Test nilai $p$ value $=0,02<(0,05)$ maka Ha diterima Ada hubungan Dukungan keluarga Pendidikan ibu Post Op Sectio Caesarea dengan pemberian kolostrum pada bayi baru lahir di RS.PMC Kota Pekanbaru tahun 2021.

Menurut Roesli (2008), menyatakan bahwa keluarga dapat berperan aktif dalam pemberian ASI terutama kolostrum dengan jalan memberikan dukungan secara emosional dan bantuan praktis lainnya seperti mengganti popok atau menyendawakan bayi. Pengetahuan yang baik mengenai kolostrum dan sikap yang mendukung, akan menentukan keberhasilan dalam pemberian kolostrum. Hal ini didukung pula dengan penelitian yang dilakukan oleh Ginting, dkk (2019) menunjukan bahwa ada hubungan antara dukungan keluarga dengan pemberian kolostrum pada 1 jam pertama kelahiran ( $p$ $=0,003)$.

Menurut analisa peneliti Dukungan keluarga sangat berpengaruh sekali dalam pemberian kolostrum, dengan adanya dukungan keluarga yang baik akan mempengaruhi pikiran ibu untuk memberikan kolostrum kepada bayinya. Pikiran negatif dari isteri akan membuat reflek oksitosin menurun. Oksitosin inilah yang menentukan keluarnya kolostrum. Tanpa oksitosin, kolostrum yang sudah diproduksi tidak dapat mengalir. Karena pikiran negatif si isteri sangat menentukan produksi kolostrum.

Oleh karena itu, keluarga harus memberikan dukungan kepada ibu saat ibu menyusui, sehingga ibu akan merasa nyaman dan senang saat memberikan kolostrum kepada bayinya. Pikiran, perasaan dan sensasi seorang ibu akan sangat mempengaruhi reflek oksitosin, yang dapat meningkatkan pengeluaran kolostrum.

\section{Kesimpulan}

1. Tingkat pendidikan ibu Mayoritas berpendidikan SMA yaitu sebanyak 24 orang responden $(80,0 \%)$.Tingkat pengetahuan $\mathrm{ibu}$ mayoritas memiliki pengetahuan yang cukup yaitu sebanyak 14 responden $(46,7 \%)$. Sebagian besar responden mendapatkan Dukungan Keluarga yang kurang baik yaitu sebanyak 20 orang responden $(66,7 \%)$.

2. Ada hubungan antara tingkat pendidikan ibu dengan pemberian kolostrum pada bayi baru lahir oleh ibu post op sectio caesarea $(p=0,10)$.

3. Ada hubungan antara tingkat pengetahuan ibu dengan pemberian kolostrum pada bayi 
baru lahir oleh ibu post op sectio caesarea $(p=0,006)$.

4. Ada hubungan antara dukungan keluarga dengan pemberian kolostrum pada bayi baru lahir oleh ibu post op sectio caesarea $(p=0,02)$.

\section{Ucapan Terimakasih}

Penulis mengucapkan terima kasih kepada Direktur Sekolah Tinggi Ilmu Kesehatan Pekanbaru Medical Center dan Ketua Lembaga Penelitian dan Pengabdian Masyarakat yang telah memberikan dukungan dalam penyelesaian publikasi ini.

\section{Daftar Pustaka}

Anasari, T. (2014). Analisis Faktor-Faktor Yang Berhubungan Dengan Pemberian Kolostrum Pada Bayi Baru Lahir. Jurnal Kebidanan, 6(1), Article 1. Http://Ejurnal.Stikeseub.Ac.Id/Index.Ph $\mathrm{p} / \mathrm{Jkeb} /$ Article/View/211

Astari, R. Y., \& Nurazizah, D. (2019). Perbandingan Metode Kolostrum Dan Metode Terbuka Terhadap Lama Pelepasan Tali Pusat Pada Bayi Baru Lahir. Faletehan Health Journal, 6(3), 91-98.

Https://Doi.Org/10.33746/Fhj.V6i3.64

Elinofia, Rita, D., \& Roma, U. (2019). Hubungan Pendidikan, Pengetahuan, Pekerjaan, Dan Dukungan Keluarga Dengan Pemberian Asi Eksklusif Di Puskesmas Sawah Lebar Kota Bengkulu. 3.

Ginting, E. P. B., Zuska, F., \& Simanjorang, A. (2019). Faktor-Faktor Yang Memengaruhi Kegagalan Inisiasi Menyusui Dini Pada Ibu Post Sectio Caesarea Di Rumah Sakit Tentara Binjai Tahun 2018. 6, 9.
Halimatusyadiah, L. (2019). Faktor-Faktor Yang Berhubungan Dengan Pemberian Kolostrum Pada Bayi Baru Lahir Di Puskesmas Curug Kota Serang Provinsi Banten Tahun 2018. Jurnal Ilmiah Kesehatan Delima, 3(1), 89-95.

Harun, A. (2017). Faktor Yang Berhubungan Dengan Pemberian Kolostrum Pada Bayi Baru Lahir Di Rskdia Pertiwi Makassar Tahun 2016. 3, 6.

Kementerian Kesehatan Ri. (2020). Situasi Dan Analisis Asi Ekslusif. Infodatin.

Maryunani, A. (2012). Inisiasi Menyusui Dini. Cv.Trans Info Medika.

Septiani, M., \& Ummami, L. (2020). FaktorFaktor Yang Memengaruhi Pemberian Kolostrum Pada Bayi Di Bpm Nurhayati, S.Sit Kecamatan Peusangan Kabupaten Bireuen. 6(1), 11.

Sitopu, S. D. (2017). Hubungan Dukungan Suami Dengan Pemberian Asi Di Kelurahan Lalang Wilayah Kerja Puskesmas Desa Lalang Kecamatan Medan Sunggal. 5.

Soetjiningsih. (2018). Seri Gizi Klinik Asi Petunjuk Untuk Tenaga Kesehatan. Egc.

Suwardi, S. (2019). Faktor Yang Berhubungan Dengan Pemberian Kolostrum Pada Bayi Baru Lahir Di Praktek Bidan Syamsiah Kabupaten Tapanuli Selatan Tahun 2018: Perawatan Payudara, Kelancaran Asi. Jurnal Ilmiah Kebidanan (Scientific Journal Of Midwifery), 5(1), 1-8. Https://Doi.Org/10.33023/Jikeb.V5i1.2 18

World Health Organization (2020). Breast Feeding Recomendation .https://www.who.int/healthtopics/breastfeeding\#tab=tab_2 